\title{
Challenges of E-Learning Technologies in Nigerian University Education
}

\author{
Olutola, Adekunle Thomas (Ph. D.) \\ Department of Educational Foundations, Faculty of Science and Education, \\ Federal University Dutsin-Ma, Katsina State, Nigeria \\ olutolaade@yahoo.com
}

\section{Olatoye, Olufunke Omotoke}

Department of Educational Foundations and Curriculum, Faculty of Education, Ahmadu Bello University, Zaira

Kaduna State, Nigeria. Odunsi_olufunke@yahoo.com

\section{Doi:10.5901/jesr.2015.v5n1p301}

\begin{abstract}
The paper examines the challenges of e-learning technologies in Nigerian University education. Education is the foundation of innovation and development. The role of e-learning in teaching and learning process cannot be overemphasized. E-learning is one of the most efficient tools for advancing knowledge, skills and development in any nation. It is necessary for quality education in Nigerian tertiary institutions. This paper reviews the concepts, benefits and challenges facing e-learning education in Nigerian Universities. The paper recommends that government at all levels, non-governmental organizations and private sectors should assist to equip university e-learning centers with model equipment for effective delivery of lectures to students with e-learning technologies.
\end{abstract}

Keywords: E-learning, Technologies, University Education, Tertiary Institutions

\section{Introduction}

Higher education is regarded as an instrument of social, political and economic development. The products of higher education in any nation will determine the development of such nation. Therefore, higher education contributes to national development through high level relevant manpower training; in order to acquire both physical and intellectual skills which enable individual to be self-reliant and useful members of the society (FRN, 2004).

According to Udokang (2006), education is the provision of opportunity for a child to realize his/her potentials, goals and abilities in life. Education includes the acquisition of functional skills, moral identity; and attribution to succeed in life and thereby improve the society (Fareo, 2012). The yearnings, needs, aspirations as well as the cultural heritage and environment of any society determine, to a large extent the kind of knowledge and skills to be acquired (Adebosin, 2004). The National Policy of Education (2004) states that education has been adopted as instrument per excellence for effecting national development.

University is the highest level of education where the high level manpower, intellectual and future leaders are developed. It is a place where students come together to pursue knowledge and it promotes the development of intellectual capacities of individuals to understand and appreciate their environments (Ajayi, 2003). Universities therefore educate future leaders and develop the high-level technical capacities that underpin economic growth and development (Odekunle, 2001). University education is at the centre of human resource development and advancement.

The World Bank/UNICEF (1996) reported that education in general, and university education in particular, is fundamental to the construction of the knowledge, economy and society in all nations. The report identified the potential of higher education system in developing countries to fulfill this responsibility is frequently thwarted by long-standing problems of finance, efficiency, equity, quality and governance. According to Ajayi and Ayodele (2002), higher education and in fact university education in Nigeria is in travail, the system is riddled with crises of various dimensions and magnitude. For Nigeria Government to proud of quality educational development especially at university level, it should be able to proud of a viable, excellent and functional e-learning driven education in our universities. 


\section{What is E-Learning?}

E-learning in learning and education refers to the use of modern technologies such as computers, digital technology, networked digital devices (e.g. the internet) and associated software and course ware (Wikipedia, 2014). E-learning as opposed to distance learning is a term that is used to refer to all ICTs, networks, internet and other forms of electronic media that can be used to enhance teaching and learning so as to transfer knowledge and skills ( Kassa \& Balunywa, 2013).

E-learning is an inclusive term that describes educational technology that electronically or technologically supports learning and teaching (Wikipedia, 2014). Parks (2013) suggested that "e-" should refer to "everything, everyone, engaging and easy" in addition to 'electronic'. Developments in internet and multimedia technologies are the basic enablers of e-learning, with consulting, content, technologies, services and support being identified as the five key sectors of the e-leaning industry (European Commission, 2000). Regardless of the educational level or stage e-learning can be adopted, used or applied in the education for effective teaching and learning. E-learning is a learner-controlled, self-paced education environment where the learner has authority over the learning environment; thereby allowing learners to work at their pace, convenience (Eke, 2011). The changes in education have led to a paradigm shift from teacher centredness through to learner centredness ( Kassa \& Balunywa, 2013). The extent to which e-learning assists or replaces other learning and teaching approaches is varied ranging on a continuum from none to fully online distance learning (Bates and Poole, 2013).

Daniel (2009) observed that e-learning plays an important role in professional development for adults in the workforce. As the world strives to meet development goals, there is increasing recognition of the potential of e-learning to meet growing educational challenges.

\section{Information Communication Technology (ICT) and E-Learning}

Information Communication Technology (ICT) refers to the totality of methods and tools that are used in gathering, storing, processing and communicating information. ICT has found application in virtually all the available professions in the world. Professionals in different fields called it by different names. When ICT is used in education or to foster learning, it is called E-learning Technology or Educational Technology. In the broadcasting profession where ICT is used as a communication tool, it is commonly referred to as Electronics Information Technology or just Communication Technology. A careful consideration of the meaning and scope of ICT makes it easy to think that hardly can any profession survive or continue to be relevant without the integration of ICT. ICT encompasses all the technologies used to transmit or disseminate information to an audience. These cover internet services provision, telecommunications equipment and services, media and broadcasting and other related information and communication activities. Modern ICT products include e-mail, voice mail, FAX, internet, electronic bulletin boards, cellular phones, videoconferencing among others.

In the teaching profession, distance education programme is now accepted world-wide as a standard alternatives mode of education due to the use of ICT (Ojokheta \&Adepoju, 2007). ICT improves instruction and more learners can be catered for. For example, Distance Education University in China has an enrolment of 1,000,000 students (Ogunsheye, 2000). In health and broadcasting sectors ICT has be used to provide information with the aim of bringing about social transformation. In Tanzania, for example, Twende na Wakat (Let's Go with Time) radio broadcast was aimed at stepping down population growth and combating HIVIAIDS infections. A survey showed that $55 \%$ of Tanzanians listened to it (Yahaya, 2003). Rogers cited by Yahaya (2003) reported that the serial had strong effect, with $23.0 \%$ of listeners reporting adoption of family planning and $82.0 \%$ reporting a method of HIV prevention. Most listeners changed to monogamous sexual relationship, while others adopted condoms or stopped sharing razors or needles.

One of the most urgent areas of highly needed infrastructure development in Nigerian higher institutions is the area of Information Communication Technology (ICT). Kozma (2005) observed that ICT is now perceived as a principal driver of economic development and social change, worldwide. It offers the potential to restructure organizations, promotes collaboration, increases democratic participation of citizens, improves transparency and responsiveness of governmental agencies. It also makes education and health care more widely available, fosters cultural creativity, and enhances the social integration of individuals with people of different abilities and cultural backgrounds. Farrel and Shafika (2007) also noted that there are widespread beliefs that ICT can be an important tool to introduce and sustain education reform efforts in Africa. 


\section{Advantages of E-Learning}

Advantages of e-learning technologies according to Bhuasiri, Xaymoungkhoun, Jeung and Cigenek (2011) include:

a. Increase in accessibility to information,

b. Better content delivery,

c. Personalized instruction,

d. Content standardization,

e. Accountability,

f. On-demand availability,

g. Self- pacing,

h. Interactivity,

i. Confidence and

j. Increased convenience

The above advantages of e-learning are based on the benefits it provides to stakeholders in educational sector. Bhuasiri, et al, (2011) noted that, in developing countries e-learning is still in its infancy and early adoption stage and the countries experience challenges unique from developed countries.

\section{Challenges of E-Learning Technologies in Nigerian Universities}

E-learning technologies development is faced with a lot of challenges in Nigerian Universities. One of these challenges is inability of teachers to assist the students develop the ability and knowledge necessary to make them use the e-learning effectively. In many e-learning projects, students face some challenges of bad perception during their studies; lack of pedagogy in their curriculum, lack of user touch and feel in their e-learning platform (Allen \& Seaman 2003; Ostund, 2005).

Also some e-learning studies conducted in developing countries show lack of vision and framework in implementing e-learning lead to failure of these e-learning projects (Pal, 2006, Kizito \& Bijan, 2006). Lack of both technical and social skills required for the implementation of e-learning contributes to failure of e-learning projects.

Four obstacles affecting the total implementation of e-learning in developing countries are:

1. Connectivity: Limited or lack of connectivity in many developing countries including Nigeria Universities impedes access to online learning e.g. (E-learning).

2. Equipment: E-learning requires equipment that can facilitate learning, but in some of Nigeria universities, the equipment such as computers, digital technology, and internet are not available for proper utilization.

3. Software: Software enables educators to design and develop learning content. These softwares are costly and not available for use in some of our universities, to facilitate e-learning programme.

4. Training: No combination of connectivity, equipment and software will achieve anything if people are not trained to use them (Daniel, 2009). Some lecturers and students are not trained to make use of some of the elearning equipment. This affect e-learning programme in our universities.

According to Judith (2004), the challenges of students in e-learning classes are:

a. Many students lack confidence and experience with computers,

b. Many students lack skills in commonly used applications such as Microsoft Word, Excel and Power Point which affects their programme in e-learning classes.

c. Time management, skills and self - motivation also influence students' performance in e-learning classes, etc.

In summary, some of the challenges of e-learning in Nigerian Universities are:-

i. Inadequate security for universities Cyber Café,

ii. Inadequate e-learning experts or manpower to train both the staff and the students,

iii. Internet facilities adopted in most universities are not functioning very well,

iv. Hardwares used for e-learning classes are costly and some universities cannot afford it,

v. Inadequate supply of electricity to e-learning centre's for effective teaching and learning,

vi. Inadequate funding of the universities to buy e-learning technologies and

vii. Inadequate laptops or computers for both the students and staffs. 


\section{Recommendations}

The following recommendations are made to promote and improve the development of e-learning education in Nigerian Universities:

i. Lecturers should be trained in appropriate skills in e-learning,

ii. Power supply should be adequate or improved upon so as to enhance the use of e-learning in our universities,

iii. Government should provide e-learning technologies to Nigeria universities to equip their e-learning centres,

iv. Government should release money to the universities for adequate funding of e-leaning centres,

v. Universities should employ capable computer experts to train Nigerian universities lecturers on how to use elearning technologies to deliver their lectures,

vi. Lecturers should be given computers to enable them prepared their e-learning lectures and notes,

vii. Private sectors, non-governmental and voluntary organizations should assist to equip universities e-learning centres,

viii. Lecturers should be adequately motivated by the federal governments and

ix. Computer engineers should be employed to help in the maintenance of the e-learning facilities in the universities and

$x$. Both the government and university administrators should provide enough security to e-learning centres in their institutions, to prevent looting of the computers by armed robbers.

\section{Conclusion}

Nigerian Universities was established to facilitate creation of new knowledge, innovation and technologies for the overall socio-economic empowerment of individual and national integration. The roles of e-learning in teaching and learning process cannot be overestimated, especially in Nigeria where emphasis in being placed on technological development. E-learning is a powerful tool that can be used to enhance and encourage teaching and learning process in universities. Through e-learning classes, students will be able to work independently and acquire more knowledge in their disciplines. Both the government and stakeholders should join hand together to ensure adequate provision of e-learning resources to our universities to facilitate technological advancement and to aid teaching and learning process.

Computer and ICT training is very important in raising the level of computer utilisation (Olatoye, 2011). Computer anxiety is also a major cause of under utilisation of computers. One of the ways of overcoming computer anxiety is to possess a computer system (Ogunkola \& Olatoye, 2008; Olatoye, 2009a,b). Continuous training in E-learning is important to improve the way staff use ICT facilities.

\section{References}

Adebosin, W.G. (2004). Agricultural Education and Empowerment of Youth's for Employment. A Paper Presented at the $3^{\text {rd }}$ National Conference Organization by Oyo State College of Education, Oyo.

Ajayi, I.A. and Ayodele, J.B. (2002). History and Development of Education. Ado Ekiti. PETOA Educational Publishers.

Ajayi, K. (2003). Minimum Standards and Accountability in University Education in B.A. Eheazu \& U.M.O. Ivowi (Eds.). Nigerian Academic of Education Proceeding of the $18^{\text {th }}$ Annual Conference, Port Harcourt; Keynote Address xcix - cx.

Allen, I.E \& Seaman, J.(2003). Sizing the Opportunity; The Quality and Extent of Online Education in the United States, 2002 and 2003. Wellesley MA: the Sloan Consortium.

Bates, A and Poole, G. (2013). Effective Teaching with Technology in Higher Education. San Francicco Jessey: Bass/John Wiley.

Bhuasiri , W. Xaymoungkhoun. O. Z. Jeung, J.R. \& Ciganek, A.P. (2011). Critical Success Factors for E-learning in Developing Countries: A Comparative Analysis Between ICT Experts and Faculty. Computers and Education, 58, 843-855.

Daniel, J. (2009). E-earning for Development: Using Information and Communications Technologies to Bridge the Digital Divide. Common Wealth Ministers Reference. Henley Media Group.

European Commission (2000). Communication from the Commission: E-learning - Designing "Tejas at Niit" Tomorrow's Education: Brussels: European Commission.

Eke, H.N. (2011). Modeling LIS Students' Intention to Adapt E-learning: A Case from University of Nigeria Nsukka, Library Philosophy and Practice .ISSN 1522- 0222.

Fareo, D.O.(2012). Schooling and Standards in Nigeria Educational System: Challenges and Prospects. Nigerian Journal of Educational Research and Evaluation, Vol. 11 , No 12 pages 30-41.

Farrel, G. \& Shafika, I. (2007). Survey of ICT and Education in Africa: A Summary Report, Based on 53 country surveys. Washington DC: infoDev/WorldBank Available: http://www.infodev.org/en/publication .353.html

Federal Republic of Nigeria (2004). National Policy on Education. Lagos: National Educational Research and Development Council 
(NERDC) Publishers.

Judith, A. P. (2004). Supporting E-learning in Higher Education. EDUCASE Center for Applied Research, Roadmap Tools for Navigating Complex Decisions. http://www.educase.edu/ecarl.

Kasse J.P and Blunywa, W. (2013). An Assessment of E-learning Utilization by a Section of Ugandan Universities Challenges, Success Factors and Way Forward. International Conference of ICT for Africa; Harare, Zimbabwe.

Kizito, B.J. \& Bijan, K. (2006). An Empirical Study on Education Strategy to E-learning in Developing Countries. Proceedings of $4^{\text {th }}$ IEEE International Workshop on Technology for Education in Developing Countries (TEDC, 06).

Kozma, R. B. (2005). National Policies that Connect ICT-Based Education Reform to Economic and Social Development, Human Technology, 1(2), 117-156.

Odekunle K.S. (2001). Funding of University Education under Democratic Rule in Nigeria: Problems and Prospects. Proceedings of the $12^{\text {th }}$ General Assembly of SSAN.

Ogunkola, B. J. \& Olatoye, R. A. (2008). Inter-Relationships among Computer Ownership, Attitudes and Literacy of Science Teachers in Ogun State, Nigeria, Journal of Applied Global Research, Vol. 1, Iss. 2, Pp.33-39.Published by Intellectbase International Consortium, Nashville, Tennessee, USA.

Ogunsheye, F.A. 2000. "Prospects for Knowledge and Information transfer managers in Nigeria in the new Millennium". In: O. Oyedele Bamisaiye I. A. Nwazuoke \& A. Okediran (Eds) Education this Millennium: Innovations in Theory and Practice, Ibadan: Macmillian

Ojokheta, K. O. \& Adepoju, T. 2007. Two-way Communication Concept and Implication for Interaction and Collaborative Learning in distance education, Ibadan Journal of Education Studies, vol.2 no.1, pp. 287-494.

Olatoye, R. A. (2009a). Influence of Computer Anxiety and Knowledge on Computer Utilization among Junior Secondary School Students, Electronic Journal of Research in Educational Psychology,Vol.10,154-159.

Olatoye, R. A. (2009b).Gender factor in Computer Anxiety, Knowledge and Utilization among Junior Secondary School Students, Gender and Behaviour, Vol. 7(2), 2430-2442. Published by Ife Centre for Psychological Studies, Ile-Ife, NIGERIA. Available at: www.e-psyche.net and www.ajol.info

Olatoye, R. A. (2011). Level of participation in ICT training programmes, computer anxiety and ICT utilization among selected professionals. International Journal of Education and Development using ICT, The University of the West Indies, Bardados, www.editlib.org/p/42202/article_42202.pdf

Ostlund, B. (2005). "Stress Disruption and Community Adult Learner's Experience of Obstacles and Opportunities in Distance Education". European Journal of open Distance and E-learning (Euro DL). 2005, ISSN 1027-520. www.eurodol.org.material/ briefostund - GBA.html.

Pal, J. (2006).Early Stage of Practical of Implementing Computer Aided Education Experience from India; Proceedings of $4^{\text {th }}$ IEEE International Workshop.

Parks, E. (2013). "What's the "e" in e-learning?". Ask International.com Retrieved 2013-10-22.

The EDUCASE top Teaching and Learning. Challenges, 2014 retrieved on 25 May 2014: (http://www.educase .edu/eli/challenges).

Udokang, S.J. (2006). Crisis in our Educational System: Challenges to Guidance Counselors. A Paper Presented at One day Workshop for Enhancing Guidance and Counseling in Akwa-Ibom State; Organized by State Secondary Education Board, Uyo.

Wikipedia (2014). E-learning. Retrieved on 25 May 2014: http://en.wikipedia.org/wiki/e- learning.

World Bank/UNICEF (1996). Senegal: Pilot Female Literacy Project. Staff Appraisal Report. No. 15517-SE. World Bank Washington. DC.

Yahaya, M.K. (2003). Development Communication. Lessons from change and social Engineering Projects. Lagos: Corporate Graphics Ltd. 
